\title{
PEMASANGAN PAPAN INFORMASI
}

\author{
NURWAHYUNI ANAS
}

9173770410159

nurwahyunianas16@gmail.com

1. Bentuk Kegiatan

$>$ Pemasangan papan informasi

2. Lokasi

$>$ Tiap Pos Ronda Desa Bontocini.

3. Hari/Tanggal dan Waktu

> Hari selasa 20 Oktober 2020 pukul 10:00 wita

4. Peserta yang Dilibatkan

> Mahasiswa KKLP Yapti Jeneponto

$>$ Karang Taruna desa Bontocini

5. Alasan diadakannya

> Alasan diadakannya pemasangan papan informasi ini adalah karena mengingat pentingnya suatu informasi ini maka kami memasang papan informasi bagi tiap-tiap pos ronda di desa Bontocini.

6. Tujuan dan Manfaat

> Tujuan dan manfaatnya yaitu untuk mempermudah penyebaran informasi kepada masyarakat desa Bontocini sehingga tidak perlu lagi mengunjungi rumah masyarakat satu persatu.

7. Produk yang dihasilkan

$>4$ buah papan informasi.

8. Deskripsi Kegiatan

$>$ Kegiatan pemasangan papan informasi ini berjalan lancar. Kami menyebarkan papan informasi ini di 4 pos ronda di 4 dusun. Pemasangan papan informasi ini dilakukan pada tanggal 20 oktober 2020. 